\title{
Kinerja Normalisasi Iluminasi Menggunakan Fungsi Imadjust Pada Pengenalan Wajah
}

\author{
Budi Nugroho \\ Program Studi Informatika, Universitas Pembangunan Nasional "Veteran” Jawa Timur \\ ${ }^{1}$ budinugroho.if@upnjatim.ac.id
}

\begin{abstract}
Abstrak - Kinerja pengenalan wajah sangat dipengaruhi oleh variasi iluminasi. Kondisi iluminasi citra wajah terjadi akibat adanya faktor pencahayaan dari sumber cahaya yang mengarah pada obyek wajah pada saat proses akuisi citra. Untuk mengurangi pengaruh faktor pencahayaan ini, proses penyesuaian citra perlu dilakukan pada tahap pra-pemrosesan untuk menormalisasi iluminasi sehingga diharapkan dapat meningkatkan kinerja pengenalan wajah. Pada penelitian ini, teknik penyesuaian kontras citra wajah dilakukan dengan menggunakan fungsi imadjust. Proses pengujian dilakukan terhadap pendekatan ini untuk mengetahui sejauhmana pengaruhnya terhadap pengenalan wajah secara lebih rinci. Melalui uji coba empiris, kinerja teknik tersebut dapat diketahui, apakah bisa digunakan pada semua kondisi pencahayaan citra ataukah tidak. Metode pengenalan wajah yang digunakan adalah Robust Regression, yang memiliki kinerja sangat baik dalam mengenali wajah yang dipengaruhi oleh variasi iluminasi. Dataset AR Face Database digunakan untuk proses uji coba, dimana dipilih citra-citra yang berkaitan dengan faktor pencahayaan, dengan tingkat kondisi pencahayaan rendah, sedang, tinggi, dan sangat tinggi (ekstrim). Skenario uji coba dilakukan dengan cara membandingkan antara hasil pengenalan wajah dengan menggunakan fungsi imadjust pada tahap pra-pemrosesan dan pengenalan wajah tanpa menggunakan teknik penyesuaian kontras citra, pada setiap kondisi pencahayaan. Berdasarkan uji coba yang telah dilakukan, fungsi imadjust menunjukkan hasil yang lebih baik daripada tanpa pra-pemrosesan pada kondisi pencahayaan sedang dan tinggi. Tetapi pada pada kondisi pencahayaan yang rendah dan ekstrim, penggunaan fungsi imadjust untuk penyesuaian kontras citra pada tahap pra-pemrosesan ternyata memberikan efek kinerja pengenalan wajah yang lebih rendah daripada tanpa pra-pemrosesan. Secara keseluruhan, penggunaan fungsi imadjust menghasilkan akurasi rata-rata pengenalan wajah sebesar $84,38 \%$ dimana hasil tersebut lebih baik daripada pengenalan wajah tanpa pra-pemrosesan.
\end{abstract}

Kata Kunci- Pengenalan Wajah, Metode Robust Regression, Variasi Iluminasi, Penyesuaian Kontras, dan Fungsi Imadjust.

\section{Pendahuluan}

Saat ini, penggunaan teknologi biometrik semakin banyak dilakukan berkaitan dengan pengenalan identitas seseorang, khususnya untuk mendukung proses otentikasi dan pengelolaan akses terbatas pada fasilitas penting [1]. Upaya ini dilakukan untuk meningkatkan standar keamanan dan memastikan bahwa sebuah fasilitas digunakan sebagaimana mestinya oleh orang yang memang memiliki lisensi untuk mengaksesnya. Dengan mobilitas orang yang saat ini sangat dinamis, tentunya teknologi biometrik memiliki peran yang makin penting dalam identifikasi dan otentikasi secara cepat dan akurat.

Salah satu teknologi biometrik yang banyak diteliti adalah pengenalan wajah. Teknik ini memiliki banyak kelebihan dan kemudahan. Proses pengenalan wajah dapat dilakukan dengan mencocokkan karakteristik wajah seseorang yang unik dengan karakteristik citra wajah yang disimpan dalam sebuah basisdata citra wajah [2]. Obyek wajah dapat diperoleh dengan mudah melalui akuisisi data citra menggunakan perangkat kamera. Kualitas kamera tentu mempengaruhi jangkauan akuisi citra serta kualitas citra wajah yang diperoleh.

Dalam perspektif penelitian, sistem pengenalan wajah masih memiliki permasalahan cukup besar yang belum sepenuhnya terselesaikan, karena tingkat kesulitannya yang memang relatif tinggi. Tidak seperti teknik biometriknya lainnya, pengenalan wajah dipengaruhi oleh banyak faktor yang cukup kompleks, antara lain faktor ekspresi wajah, perubahan fisik, faktor usia, atribut di wajah, gender, posisi, iluminasi, noise, dan sebagainya.

Pada penelitian ini, pengenalan wajah dipengaruhi oleh kondisi pencahayaan atau variasi iluminasi, dimana faktor ini masih memiliki masalah yang cukup kompleks. Kondisi pencahayaan yang berbeda pada sebuah wajah dari satu orang, dengan posisi dan ekspresi yang sama, dapat memungkinkan mengenalinya sebagai wajah dari beberapa orang yang berbeda [3]. Variasi iluminasi dianggap sebagai salah satu masalah utama berkaitan dengan tingkat kehandalan sistem pengenalan wajah [4]. Bahkan pada penelitian sebelumnya menunjukkan bahwa variasi iluminasi lebih berpengaruh pada pengenalan wajah dibandingkan dengan variasi lainnya, misalnya posisi atau ekspresi [5]. Khususnya pada kondisi pencahayaan yang kompleks, masalah ini belum sepenuhnya terpecahkan. Hal inilah yang kemudian memunculkan banyak penelitian untuk memecahkan persoalan ini. Para peneliti terus berusaha mengidentifikasi masalah dan menganalisisnya untuk menemukan cara bagaimana meningkatkan kinerja pengenalan wajah yang dipengaruhi oleh faktor pencahayaan khususnya pada kondisi variasi pencahayaan yang tidak teratur dan kompleks [6].

Variasi iluminas pada obyek wajah sangat mempengaruhi proses pengenalan wajah. Oleh karena itu, proses penyesuaian kontras citra seringkali dilakukan pada tahap pra-pemrosesan pengenalan wajah untuk menormalisasi iluminasi citra. Tetapi, tahap penyesuaian kontras citra ini tidak mudah juga dilakukan untuk benar-benar bisa menghasilkan kinerja yang optimal [7]. 
Banyak metode yang dikembangkan oleh pada peneliti untuk memecahkan masalah kinerja pengenalan wajah yang dipengaruhi oleh variasi iluminasi. Salah satu metode yang memiliki kinerja pengenalan wajah cukup baik adalah Robust Regression [8]. Metode ini dikembangkan lagi untuk mengurangi pengaruh noise pada citra wajah. Pada tahap prapemrosesan, proses normalisasi iluminasi citra dilakukan dengan menggunakan teknik penyesuaian kontras citra.

Pada penelitian ini, teknik penyesuaian kontras citra yang digunakan pada tahap pra-pemrosesan pengenalan wajah adalah fungsi imadjust. Penelitian dilakukan untuk mengetahui apakah penggunaan teknik ini dapat memberikan kontribusi positif pada kinerja pengenalan wajah. Pengujian empiris dilakukan untuk mengetahui secara lebih rinci pengaruhnya pada sejumlah kondisi pencahayaan citra. Secara teoritis, fungsi imadjust sebagai salah satu teknik penyesuaian kontras citra memiliki kemampuan untuk menormalisasi semua citra dengan variasi kondisi pencahayaannya sehingga memiliki tingkat kekontrasan yang relatif sama, sehingga kinerja pengenalan wajah menjadi lebih baik. Tetapi kesimpulan ini perlu diteliti lebih dalam lagi untuk mengetahu efektivitasnya pada setiap kondisi iluminasi wajah, sebagaimana dilakukan pada penelitian ini.

\section{Metodologi Penelitian}

Pendekatan pengenalan wajah yang digunakan dalam penelitian ini adalah metode Robust Regression. Pada tahap pre-pocessing, teknik penyesuaian kontras citra wajah dilakukan dengan menggunakan fungsi imadjust. Nantinya juga akan dilakukan implementasi metode robust regression tanpa disertai dengan tahap pra-pemrosesan (tidak ada proses penyesuaian kontras citra). Hal ini dilakukan untuk mengetahui sejauhmana pengaruh penggunaan fungsi imadjust pada kinerja pengenalan wajah. Uji coba dilakukan dengan menggunakan sebuah dataset citra wajah, yaitu AR Face Database [9]. Proses pengenalan wajah dilakukan berdasarkan citra training pada setiap kondisi pencahayaan.

\section{A. Metode Pengenalan Wajah}

Diantara berbagai metode pengenalan wajah yang telah dikembangkan oleh para peneliti untuk menangani masalah iluminasi citra wajah dapat dikategorikan menjadi beberapa pendekatan, yaitu: pendekatan berbasis model, pendekatan berbasis ciri/fitur, serta pendekatan pra-pemrosesan.

Pendekatan berbasis model didasarkan pada sub-ruang linier berdimensi rendah untuk mengurangi pengaruh iluminasi pada citra wajah. Beberapa contoh dari pendekatan ini antara lain Illumination Cone [10] dan Spherical Harmonic [11]. Pendekatan ini memiliki kelemahan diantaranya banyak citra wajah yang diperlukan untuk membangun ruang linier, sehingga akan menyulitkan dalam menangani basisdata besar.

Pada pendekatan berbasis ciri, proses pengenalan wajah menggunakan ciri invarian iluminasi. Beberapa contoh dari metode ini adalah 2D Gabor-like Filters [12], Discrete Cosine Transform / DCT [5], dan Local Binary Pattern [13].

Sedangkan pada pendekatan pra-pemrosesan, proses pengenalan wajah dilakukan dengan menggunakan teknik penyesuaian kontras citra untuk melakukan normalisasi iluminasi terhadap citra wajah. Beberapa contoh dari metode ini diantaranya Quotient Image / QI, Self-Quotient Image / SQI, dan Robust Regression. Pendekatan ini terbukti mampu meningkatkan kinerja pengenalan wajah yang dipengaruhi variasi iluminasi. Gbr. 1 menunjukkan sistem pengenalan wajah secara umum dengan menggunakan normalisasi iluminasi pada tahap pra-pemrosesan.

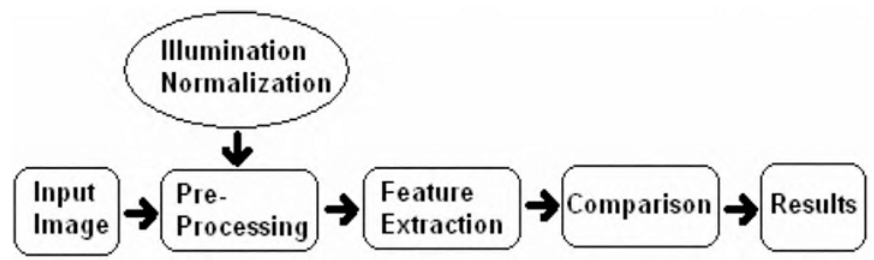

Gbr. 1 Sistem Pengenalan Wajah dengan tahap pra-pemrosesan untuk menormalkan iluminasi citra wajah [14]

Metode Robust Regression yang digunakan pada penelitian ini menggunakan pendekatan pra-pemrosesan, dimana proses penyesuaian kontras citra dilakukan untuk menormalkan citra wajah akibat pengaruh iluminasi. Proses pelatihan data dilakukan untuk membangun model mesin pengklasifikasi untuk menghasilkan sebuah regressor/predictor untuk setiap kelas/individu. Tahap pra-pemrosesan diperlukan sebelum proses klasifikasi, dimana citra wajah berukuran a $\mathrm{x}$ b terlebih dahulu dilakukan normalisasi iluminasi menggunakan fungsi imadjust. Selanjutnya, matriks citra training tersebut diubah menjadi vektor berdimensi lebih kecil dengan nilai maksimum 1 dan penyusunan regressor/predictor dilakukan untuk masing-masing kelas menggunakan gabungan vektor training. Setelah proses pelatihan data dilakukan, proses pengujian dilakukan untuk mengklasifikasikan data uji ke dalam salah satu kelas menggunakan predictor (yang dihasilkan pada saat proses pelatihan sebelumnya). Proses penyesuaian kontras citra menggunakan fungsi imadjust juga dilakukan terhadap citra wajah yang akan diuji. Selanjutnya, matriks citra uji tersebut diubah menjadi vektor berdimensi lebih kecil dengan nilai maksimum 1 dan kelas citra uji diprediksi dengan menggunakan hasil estimasi huber dengan jarak terkecil.

\section{B. Penyesuaian Kontras Citra Wajah}

Proses penyesuaian kontras citra umumnya dilakukan pada tahap pra-pemrosesan, baik saat pelatihan data maupun proses klasifikasi (tahap pengujian). Proses ini dilakukan untuk mengurangi pengaruh yang ditimbulkan akibat variasi kondisi pencahayaan pada citra. Faktor pencahayaan ini memiliki pengaruh kuat pada kekontrasan citra, yang memiliki pengaruh pada kinerja klasifikasi data termasuk pada pengenalan wajah. Melalui proses penyesuaian kontras ini, tingkat kekontrasan dari semua citra memiliki kemiripan sehingga lebih mudah untuk diklasifikasikan, sehingga kinerja pengenalan wajah diharapkan menjadi lebih baik.

Pada penelitian ini, fungsi imadjust digunakan untuk melakukan penyesuaian kontras citra dan nantinya dibandingkan hasilnya dengan pengenalan wajah yang tidak menggunakan teknik tersebut (tanpa tahap pra-pemrosesan), sehingga dapat diketahui secara terukur sejauhmana pengaruh fungsi tersebut pada kinerja pengenalan wajah. 


\section{Dataset Citra Wajah}

Proses uji coba pada penelitian ini menggunakan kumpulan citra wajah pada AR Face Database. Pada basisdata ini, setiap orang yang diambil gambar wajahnya memuat variasi ekspresi wajah, kondisi iluminasi, dan illumination conditions and penghalang/penutup bagian tertentu wajah. Setiap gambar diambil menggunakan teknik pengambilan data yang dilakukan pada lingkungan yang telah dirancang sedemikian rupa berdasarkan standar kebutuhan terkait faktor iluminasi.

TABEL I

CONTOH CITRA WAJAH DENGAN VARIASI PENCAHAYAAN: M-001

\begin{tabular}{|c|c|c|c|}
\hline $\begin{array}{c}\text { Kondisi } \\
\text { Pencahayaan }\end{array}$ & Sesi & $\begin{array}{c}\text { Nomor } \\
\text { Citra }\end{array}$ & Gambar Citra \\
\hline Rendah & 1 & 01 & \\
\hline Sedang & 1 & 05 & \\
\hline Tinggi & 1 & 06 & \\
\hline $\begin{array}{c}\text { Sangat Tinggi } \\
\text { (Ekstrim) }\end{array}$ & 1 & 07 & \\
\hline $\begin{array}{c}\text { Rendah } \\
\text { Sedang }\end{array}$ & 2 & 14 & \\
\hline (Ekstrim) & 2 & 20 & \\
\hline Tinggi & 2 & 19 & \\
\hline
\end{tabular}

Uji coba pada penelitian ini menggunakan data citra wajah dari 100 orang (50 laki-laki and 50 perempuan) dengan kondisi citra wajah pada ekspresi netral, tampak depan, dan variasi kondisi pencahayaan. Setiap citra wajah berukuran 100x100 piksel dan terbagi ke dalam 2 sesi citra wajah pada setiap orang. Setiap sesi tersebut memuat 4 variasi pencahayaan: rendah (citra wajah dengan intensitas pencahayaan yang rendah dari sumber cahaya arah depan), sedang (citra wajah dengan intensitas pencahayaan yang sedang dari sumber cahaya arah samping), tinggi (citra wajah dengan intensitas pencahayaan yang tinggi dari sumber cahaya arah samping) dan sangat tinggi / ekstrim (Citra wajah dengan intensitas pencahayaan yang sangat tinggi dari sumber cahaya arah depan). Tabel I menunjukkan contoh dari salah satu orang dengan variasi pencahayaan pada AR Face Database yang digunakan para penelitian ini. Sesi citra merupakan sesi pengambilan gambar pada satu posisi yang sama dengan beberapa variasi pencahayaan. Sehingga, dalam proses pengujian pada uji coba penelitian ini dilakukan pada citra dalam sesi yang sama. Hal ini dilakukan untuk benarbenar mengetahui pengaruh dari proses penyesuaian citra dengan menggunakan fungsi imadjust yang berkaitan dengan kondisi pencahayaan sebuah citra.

\section{Skenario Uji Coba}

Proses pengujian dilakukan dengan memilih citra wajah pada setiap kondisi pencahayaan pada setiap sesi, sebagaimana ditunjukkan pada tabel II. Skenario uji coba 1 dilakukan dengan menggunakan citra latih nomor 01 dan 14 yang memiliki kondisi pencahayaan rendah. Skenario uji coba 2 dilakukan dengan menggunakan citra latih nomor 05 dan 18 yang memiliki kondisi pencahayaan sedang. Skenario uji coba 3 dilakukan dengan menggunakan citra latih nomor 06 dan 19 yang memiliki kondisi pencahayaan tinggi. Dan skenario uji coba 4 dilakukan dengan menggunakan citra latih nomor 07 dan 20 yang memiliki kondisi pencahayaan sangat tinggi (ekstrim).

TABEL III

SKENARIO UJI COBA

\begin{tabular}{|c|c|c|c|}
\hline $\begin{array}{c}\text { Skenario } \\
\text { Uji Coba }\end{array}$ & Sesi & $\begin{array}{c}\text { Nomor } \\
\text { Citra Latih }\end{array}$ & $\begin{array}{c}\text { Nomor } \\
\text { Citra Uji }\end{array}$ \\
\hline \multirow{2}{*}{1} & 1 & 01 & $05,06,07$ \\
\cline { 2 - 4 } & 2 & 14 & $18,19,20$ \\
\hline \multirow{2}{*}{2} & 1 & 05 & $01,06,07$ \\
\cline { 2 - 4 } & 2 & 18 & $14,19,20$ \\
\cline { 2 - 4 } 3 & 1 & 06 & $01,05,07$ \\
\hline \multirow{2}{*}{4} & 2 & 19 & $14,18,20$ \\
\cline { 2 - 4 } & 1 & 07 & $01,05,06$ \\
\hline
\end{tabular}

Uji coba dilakukan untuk mengetahui kinerja pengenalan wajah (menggunakan parameter akurasi dalam ukuran persen) dengan menggunakan metode robust regression, dengan prapemrosesan menggunakan fungsi imadjust dan tanpa prapemrosesan (tanpa proses penyesuaian citra). Selanjutnya, hasil dari keduanya akan dibandingkan untuk mengetahui mana yang menghasilkan kinerja lebih baik.

\section{HASIL DAN PEMBAHASAN}

Bagian Hasil dan Pembahasan ini akan dipaparkan hasil pengujian yang telah dilakukan berdasarkan skenario uji coba yang telah ditentukan pada bagian sebelumnya. Ada 4 hasil pengujian yang diperoleh, yaitu hasil pengujian dengan citra latih pada kondisi pencahayaan rendah, sedang, tinggi, dan sangat tinggi (ekstrim).

Tabel III menunjukkan hasil uji coba dengan citra latih pada kondisi pencahayaan rendah. Pada sesi 1, fungsi imadjust menunjukkan kinerja yang buruk, dimana hasilnya lebih rendah daripada pengenalan wajah tanpa pra-pemrosesan. Demikian juga pada sesi 2, fungsi imadjust menunjukkan kinerja yang buruk, dimana hasilnya lebih rendah daripada pengenalan wajah tanpa pra-pemrosesan. Akurasi rata-rata dari kinerja fungsi imadjust adalah $82,83 \%$, lebih rendah $3,67 \%$ daripada kinerja tanpa pra-pemrosesan yang memiliki akurasi sebesar $86,50 \%$. Hal ini menunjukkan bahwa penggunaan fungsi imadjust untuk penyesuaian kontras citra pada tahap pra-pemrosesan memberikan dampak negatif pada 
kinerja pengenalan wajah pada citra latih dengan kondisi pencahayaan rendah.

TABEL IIIII

HASIL UJI COBA 1

\begin{tabular}{|c|c|c|c|c|}
\hline \multirow{2}{*}{ Sesi } & $\begin{array}{c}\text { Citra } \\
\text { Latih }\end{array}$ & $\begin{array}{c}\text { Citra } \\
\text { Uji }\end{array}$ & $\begin{array}{c}\text { Akurasi } \\
\text { Imadjust }\end{array}$ & $\begin{array}{c}\text { Akurasi Tanpa } \\
\text { Pra-pemrosesan }\end{array}$ \\
\hline \multirow{3}{*}{1} & 01 & 05 & $82,00 \%$ & $88,00 \%$ \\
\cline { 2 - 5 } & 01 & 06 & $79,00 \%$ & $87,00 \%$ \\
\cline { 2 - 5 } & 01 & 07 & $77,00 \%$ & $84,00 \%$ \\
\hline \multicolumn{2}{|c|}{ Akurasi rata-rata Sesi 1} & $79,33 \%$ & $86,33 \%$ \\
\hline \multirow{3}{*}{2} & 14 & 18 & $90,00 \%$ & $96,00 \%$ \\
\cline { 2 - 5 } & 14 & 19 & $83,00 \%$ & $88,00 \%$ \\
\cline { 2 - 5 } & 14 & 20 & $86,00 \%$ & $76,00 \%$ \\
\hline \multicolumn{2}{|c|}{ Akurasi rata-rata Sesi 2} & $86,33 \%$ & $86,67 \%$ \\
\hline \multicolumn{3}{|c|}{ Akurasi rata-rata } & $82,83 \%$ & $86,50 \%$ \\
\hline
\end{tabular}

Tabel IV menunjukkan hasil uji coba dengan citra latih pada kondisi pencahayaan sedang. Pada sesi 1, fungsi imadjust menunjukkan kinerja yang baik, dimana hasilnya lebih tinggi daripada pengenalan wajah tanpa pra-pemrosesan. Demikian juga pada sesi 2, fungsi imadjust menunjukkan kinerja yang baik, dimana hasilnya lebih tinggi daripada pengenalan wajah tanpa pra-pemrosesan. Akurasi rata-rata dari kinerja fungsi imadjust adalah $83,33 \%$, lebih tinggi 9,00\% daripada kinerja tanpa pra-pemrosesan yang memiliki akurasi sebesar 74,33\%. Hal ini menunjukkan bahwa penggunaan fungsi imadjust untuk penyesuaian kontras citra pada tahap pra-pemrosesan memberikan dampak positif pada kinerja pengenalan wajah pada citra latih dengan kondisi pencahayaan sedang.

TABEL IVV

HASIL UJI COBA 2

\begin{tabular}{|c|c|c|c|c|}
\hline \multirow{2}{*}{ Sesi } & $\begin{array}{c}\text { Citra } \\
\text { Latih }\end{array}$ & $\begin{array}{c}\text { Citra } \\
\text { Uji }\end{array}$ & $\begin{array}{c}\text { Akurasi } \\
\text { Imadjust }\end{array}$ & $\begin{array}{c}\text { Akurasi Tanpa } \\
\text { Pra-pemrosesan }\end{array}$ \\
\hline \multirow{3}{*}{1} & 05 & 01 & $90,00 \%$ & $86,00 \%$ \\
\cline { 2 - 5 } & 05 & 06 & $67,00 \%$ & $54,00 \%$ \\
\cline { 2 - 5 } & 05 & 07 & $86,00 \%$ & $84,00 \%$ \\
\hline \multicolumn{2}{|c|}{ Akurasi rata-rata Sesi 1} & $81,00 \%$ & $74,67 \%$ \\
\hline \multirow{3}{*}{2} & 18 & 14 & $92,00 \%$ & $88,00 \%$ \\
\cline { 2 - 5 } & 18 & 19 & $78,00 \%$ & $51,00 \%$ \\
\cline { 2 - 5 } & 18 & 20 & $87,00 \%$ & $83,00 \%$ \\
\hline \multicolumn{3}{|c|}{ Akurasi rata-rata Sesi 2} & $85,67 \%$ & $74,00 \%$ \\
\hline \multicolumn{3}{|c|}{ Akurasi rata-rata } & $83,33 \%$ & $74,33 \%$ \\
\hline
\end{tabular}

Tabel V menunjukkan hasil uji coba dengan citra latih pada kondisi pencahayaan tinggi. Pada sesi 1 , fungsi imadjust menunjukkan kinerja yang baik, dimana hasilnya lebih tinggi daripada pengenalan wajah tanpa pra-pemrosesan. Demikian juga pada sesi 2, fungsi imadjust menunjukkan kinerja yang baik, dimana hasilnya lebih tinggi daripada pengenalan wajah tanpa pra-pemrosesan. Akurasi rata-rata dari kinerja fungsi imadjust adalah $80,17 \%$, lebih tinggi $8,83 \%$ daripada kinerja tanpa pra-pemrosesan yang memiliki akurasi sebesar $71,33 \%$. Hal ini menunjukkan bahwa penggunaan fungsi imadjust untuk penyesuaian kontras citra pada tahap pra-pemrosesan memberikan dampak positif pada kinerja pengenalan wajah pada citra latih dengan kondisi pencahayaan tinggi.
TABEL V

HASIL UJI COBA 3

\begin{tabular}{|c|c|c|c|c|}
\hline \multirow{2}{*}{ Sesi } & $\begin{array}{c}\text { Citra } \\
\text { Latih }\end{array}$ & $\begin{array}{c}\text { Citra } \\
\text { Uji }\end{array}$ & $\begin{array}{c}\text { Akurasi } \\
\text { Imadjust }\end{array}$ & $\begin{array}{c}\text { Akurasi Tanpa } \\
\text { Pra-pemrosesan }\end{array}$ \\
\hline \multirow{3}{*}{1} & 06 & 01 & $88,00 \%$ & $80,00 \%$ \\
\cline { 2 - 5 } & 06 & 05 & $68,00 \%$ & $45,00 \%$ \\
\cline { 2 - 5 } & 06 & 07 & $96,00 \%$ & $94,00 \%$ \\
\hline \multicolumn{2}{|c|}{ Akurasi rata-rata Sesi 1} & $84,00 \%$ & $73,00 \%$ \\
\hline \multirow{3}{*}{2} & 19 & 14 & $83,00 \%$ & $77,00 \%$ \\
\cline { 2 - 5 } & 19 & 18 & $55,00 \%$ & $47,00 \%$ \\
\cline { 2 - 5 } & 19 & 20 & $91,00 \%$ & $85,00 \%$ \\
\hline \multicolumn{6}{|c|}{ Akurasi rata-rata Sesi 2} & $76,33 \%$ & $69,67 \%$ \\
\hline \multicolumn{6}{|c|}{ Akurasi rata-rata } & $80,17 \%$ & $71,33 \%$ \\
\hline
\end{tabular}

Sedangkan pada Tabel VI ditunjukkan hasil uji coba dengan citra latih pada kondisi pencahayaan sangat tinggi (ekstrim). Pada sesi 1, fungsi imadjust menunjukkan kinerja yang buruk, dimana hasilnya lebih rendah daripada pengenalan wajah tanpa pra-pemrosesan. Demikian juga pada sesi 2, fungsi imadjust menunjukkan kinerja yang buruk, dimana hasilnya lebih rendah daripada pengenalan wajah tanpa pra-pemrosesan. Akurasi rata-rata dari kinerja fungsi imadjust adalah $91,17 \%$, lebih rendah 3,50\% daripada kinerja tanpa pra-pemrosesan yang memiliki akurasi sebesar $94,67 \%$. Hal ini menunjukkan bahwa penggunaan fungsi imadjust untuk penyesuaian kontras citra pada tahap pra-pemrosesan memberikan dampak negatif pada kinerja pengenalan wajah pada citra latih dengan kondisi pencahayaan rendah.

TABEL VI

HASIL UJI COBA 4

\begin{tabular}{|c|c|c|c|c|}
\hline Sesi & $\begin{array}{c}\text { Citra } \\
\text { Latih }\end{array}$ & $\begin{array}{c}\text { Citra } \\
\text { Uji }\end{array}$ & $\begin{array}{c}\text { Akurasi } \\
\text { Imadjust }\end{array}$ & $\begin{array}{c}\text { Akurasi Tanpa } \\
\text { Pra-pemrosesan }\end{array}$ \\
\hline \multirow{3}{*}{1} & 07 & 01 & $86,00 \%$ & 90,00 \\
\cline { 2 - 5 } & 07 & 05 & 89,00 & 97,00 \\
\cline { 2 - 5 } & 07 & 06 & 99,00 & 99,00 \\
\hline \multicolumn{2}{|c|}{ Akurasi rata-rata Sesi 1} & 91,33 & 95,33 \\
\hline \multirow{3}{*}{2} & 20 & 14 & 86,00 & 91,00 \\
\cline { 2 - 5 } & 20 & 18 & 91,00 & 95,00 \\
\cline { 2 - 5 } & 20 & 19 & 96,00 & 96,00 \\
\hline \multicolumn{3}{|c|}{ Akurasi rata-rata Sesi 2} & 91,00 & 94,00 \\
\hline \multicolumn{6}{|c|}{ Akurasi rata-rata } & 91,17 & 94,67 \\
\hline
\end{tabular}

\section{KESIMPULAN DAN SARAN}

Berdasarkan hasil uji coba yang telah dilakukan, proses penyesuaian citra wajah dengan menggunakan fungsi imadjust menghasilkan kinerja pengenalan wajah yang lebih baik pada citra latih dengan kondisi pencahayaan sedang dan tinggi. Tetapi pada citra latih dengan kondisi pencahayaan rendah dan sangat tinggi (ektrim), penggunaan fungsi imadjust pada tahap pra-pemrosesan ternyata memberikan efek kinerja pengenalan wajah yang lebih buruk.

Hasil penelitian ini memberikan informasi penting bahwa proses penyesuaian kontras citra untuk normalisasi iluminasi pada tahap pra-pemrosesan pengenalan wajah yang dipengaruhi oleh faktor iluminasi ternyata tidak selalu efektif pada semua kondisi pencahayaan. Setiap kondisi pencahayaan 
pada citra wajah memerlukan pendekatan yang berbeda untuk menghasilkan kinerja pengenalan wajah yang paling optimal.

Untuk pengembangan penelitian selanjutnya, pengujian perlu dilakukan terhadap teknik penyesuaian kontras citra lainnya, untuk mengetahui apakah menunjukkan hasil yang sama dengan teknik yang diterapkan pada penelitian ini. Sehingga nantinya dapat diketahui teknik penyesuaian kontras citra wajah yang paling efektif untuk digunakan pada setiap kondisi pencahayaan.

\section{UCAPAN TERIMA KASIH}

Kami mengucapkan Terima kasih kepada Program Studi Informatika dan Fakultas Ilmu Komputer UPN "Veteran" Jawa Timur yang menyediakan fasilitas selama proses penelitian ini sehingga dapat menghasilkan luaran yang diharapkan.

\section{REFERENSI}

[1] R. Jafri and H.R. Arabnia, A Survey of Face Recognition Techniques, Journal of Information Processing Systems, Vol.5, No.2, June 2009.

[2] W. Zhao, R. Chellappa, P.J. Phillips, A. Rosenfeld, Face recognition: a literature survey, ACM Comput. Surv. vol. 35, pp. 399-458, 2003.

[3] M. Singha and A.S. Arora, Varying Illumination and Pose Conditions in Face Recognition, Procedia Computer Science, 2016.

[4] Andrea F. Abate, Michele Nappi, Daniel Riccio, Gabriele Sabatino, 2D and 3D face recognition: A survey, Journal of Pattern Recognition, 2007.
[5] Haifeng Hu, Multiscale illumination normalization for face recognition using dual-tree complex wavelet transform in logarithm domain, Journal of Computer Vision and Image Understanding, 2011.

[6] H. Kusuma, Wirawan, and A. Soeprijanto, Face Recognition Against Varying Lighting Conditions Using Oriented Phase Congruency Image Features, Journal of Theoretical and Applied Information Technology, 2016.

[7] J. Yi, X. Mao, L. Chen, Y. Xue, A. Rovetta, and C.D. Caleanu, Illumination Normalization of Face Image Based on Illuminant Direction Estimation and Improved Retinex, PLoS One, 2015.

[8] I. Naseem, R. Togneri, M. Bennamoun, Robust Regression For Face Recognition, Journal of Pattern Recognition, 2012.

[9] A. Martinez and R. Benavente, The AR face database, Technical Report 24, CVC, 1998.

[10] Athinodoros S. Georghiades, Peter N. Belhumeur, David J. Kriegman, From Few to Many: Illumination Cone Models for Face Recognition under Variable Lighting and Pose, IEEE Transactions on Pattern Analysis and Machine Intelligence, 2001.

[11] Xiaoyue Jiang, Yinglei Cheng, Rong Xiao, Ying Li, Rongchun Zhao, Spherical harmonic based linear face de-lighting and compensation, Applied Mathematics and Computation, 2007.

[12] Al-Amin Bhuiyan, Chang Hong Liu, On Face Recognition using Gabor Filters, World Academy of Science, Engineering and Technology, 2007.

[13] Timo Ahonen, Abdenour Hadid, Matti Pietikainen, Face Recognition with Local Binary Patterns, Machine Vision Group, Infotech Oulu, Finland, 2004.

[14] M. Sharif, S. Mohsin, M. J. Jamal, M. Raza, Illumination normalization preprocessing for face recognition, Conference on Environmental Science and Information Application Technology, 2010. 